Zusammenfassung. Der Calorienbedarf bei schwerkranken Schädel-Hirnverletzten beträgt pro Tag etwa 4000-5000 Calorien. Zur Deckung dieses Bedarfs müßten bei parenteraler Ernährung große Flüssigkeitsmengen infundiert und damit auch die Gefahren eines Hirnödems und einer Kreislaufüberlastung in Kauf genommen werden. Außerdem würden manche Substanzen (z. B. Fette) relativ zu schnell infundiert, zu einer hohen Serumkonzentration führen, die Nierenschwelle überschreiten und nicht mehr stoffwechselwirksam sein. Im Gegensatz zur parenteralen Nahrungszufuhr ist bei Sondenernährung lediglich eine Flüssigkeitsmenge von $2500 \mathrm{ml}$ erforderlich. Eine spezielle Zusammensetzung dieser Sondennahrung - mit einem Fettanteil etwas unter dem idealen Wert - wird diskutiert. Für die klinische Praxis wird vorgeschlagen, wegen der meist vorhandenen Atonie des Magen-Darmtraktes und der damit vorhandenen Fermentstörung anfänglich rein parenteral zu ernähren und erst vom 3. Tag an allmählich auf Sondennahrung überzugehen.

\title{
156c. Thrombocytenaggregation im traumatischen Schock
}

\section{Loww-Rüsselsheim}

\section{Thrombocyte Aggregation in Traumatic Shock}

Summary. For the differentiation of the early stage of acute shock from the protracted form of haemorrhagic or traumatic shock constant control of the thrombocyte count and especially thrombocyte function is considered indispensable. 3 facts are responsible for the fall in thrombocytes: 1 . blood loss, 2. dilution by infusion and 3. haemostasis and intravasal aggregation. If during shock treatment thrombocyte function remains reduced or even gets worse (as was shown in Breddin's aggregation test in $\mathbf{1 6}$ severely injured patients), the prognosis is generally unfavourable. Although morphologically there is no secondary DIC (disseminated intravasal coagulation) in these cases, there is an increase of mature and immature blood and bone marrow cells. In view of the findings the use of aggregation inhibitors is recommended even in the early phase of acute traumatic shock.

Zusammenfassung. Zur Differenzierung des Frühstadiums des akuten Schocks von der protrahierten Form des hämorrhagischen oder traumatischen Schocks wird eine ständige Kontrolle der Thrombocytenzahl und besonders der Thrombocytenfunktion für unerläßlich erachtet. Für den Thrombocytenabfall werden 3 V's verantwortlich gemacht.

1. Verlust durch Blutung,

2. Verdünnung durch Infusion und

3. Verbrauch durch Hämostase und intravasale Aggregation.

Bleibt im Verlaufe der Schocktherapie die Thrombocytenfunktion - wie bei 16 Schwerverletzten im Aggregationstest nach Breddin nachgewiesen werden konnte - gesteigert oder verschlechtert sie sich noch, ist die Schockprognose in der Regel ungünstig. Morphologisch wird dann zwar sekundär nicht immer eine DIC (Disseminierte intravasale Coagulation) gefunden, aber eine Vermehrung reifer und unreifer Blut- und Knochenmarkszellen. Auf Grund der Untersuchungen wird bereits in der Frühphase des akuten traumatischen Schocks der Einsatz von Aggregationshemmern empfohlen. 